Table 4. List of localities for inventory of the project 'Vandkraftundersøgelser for bynare bassiner'

\begin{tabular}{|c|c|c|c|c|}
\hline Name of locality & $\begin{array}{l}\text { Number of } \\
\text { local glaciers }\end{array}$ & $\begin{array}{l}\text { Total area of } \\
\text { local glaciers } \\
\text { in } \mathrm{km}^{2}\end{array}$ & $\begin{array}{l}\text { Local glaciers } \\
\text { as \% of total } \\
\text { basin area }\end{array}$ & $\begin{array}{l}\text { Lobes from the } \\
\text { Inland Ice }\end{array}$ \\
\hline $\begin{array}{l}\text { Tasiussârssuk } \\
\text { Taseq } \\
\text { Iterdlâ } \\
\text { Kangârssap taserssua } \\
\text { Isortuarssap tasia } \\
\text { Buksef jorden } \\
\text { Qapiarfiup sermia } \\
\text { Taserssuaq } \\
\text { Kagssap tasia } \\
\text { Pâkitsoq } \\
\text { Laksebugt } \\
\text { Radeelv } \\
\text { Brededal } \\
\text { Daugaard-Jensens Dal } \\
\text { Angmagssalik } 1 \\
\\
2 \\
3\end{array}$ & $\begin{array}{r}8 \\
1 \\
0 \\
17 \\
45 \\
35 \\
9 \\
35 \\
0 \\
0 \\
25 \\
10 \\
9 \\
34 \\
18 \\
6 \\
5\end{array}$ & $\begin{array}{c}0.95 \\
1.4 \\
0 \\
11.28 \\
205.7 \\
15.9 \\
30.8 \\
40 \\
0 \\
0 \\
14.5 \\
18.1 \\
10.4 \\
137.4 \\
10.0 \\
2.2 \\
2.5\end{array}$ & $\begin{array}{c}5.6 \\
8.2 \\
0 \\
4 \\
26.5 \\
2.3 \\
54 \\
4.9 \\
0 \\
0 \\
11.4 \\
20.7 \\
18.6 \\
54.4 \\
10.9 \\
8.4 \\
15.4\end{array}$ & $\begin{array}{r}0 \\
0 \\
2 \\
12 \\
1 \\
0 \\
0 \\
0 \\
5 \\
9 \\
0 \\
0 \\
0 \\
0 \\
0 \\
0 \\
0\end{array}$ \\
\hline & 257 & 500 & & 29 \\
\hline
\end{tabular}

basins, the investigations were supplemented with work on a small glacier in Buksefjord and at the Inland Ice margin at Pâkitsoq.

\title{
A glaciological field and mapping programme in connection with hydropower, West Greenland
}

\section{Henrik Højmark Thomsen}

As part of the GGU programme for mapping the hydroelectric potential of West Greenland, glaciological field work and glacier mapping have been started in areas proposed for local hydropower projects.

\section{Glaciological field work in Pâkitsoq}

Glaciological investigations were started on the Inland Ice north-west of Jakobshavn in August 1982. The meltwater from this part of the Inland Ice makes up a large part of the runoff from a basin which has been proposed for a local hydropower project $(\mathrm{GTO}, 1982)$. 
The drainage basin. The drainage basin at Pâkitsoq lies between $69^{\circ} 25^{\prime} \mathrm{N}$ to $69^{\circ} 32^{\prime} \mathrm{N}$ and $50^{\circ} 05^{\prime} \mathrm{W}$ to $50^{\circ} 20^{\prime} \mathrm{W}$ (fig. 38). The basin excluding its Inland Ice sector covers an area of $33.6 \mathrm{~km}^{2}$, and is situated at about $200-600 \mathrm{~m}$ above sea level. Adjoining this area to the east is a sector of the Inland Ice with an estimated area of $788 \mathrm{~km}^{2}$ (based on 1:250000 topographic map sheets). Besides the outlet glaciers from the Inland Ice (inventory numbers 1GE07001-2, 1GE04001-2) the basin contains no local glaciers. The transient snow line on this part of the Inland Ice was about $1200-1300 \mathrm{~m}$ at the beginning of September 1980 (Landsat imagery).

Field work. The field work was carried out with the assistance of a helicopter. Stakes for measuring accumulation and ablation were drilled into the ice at different altitudes (fig. 38). The start point of the stake network is situated on the glacier 1GE07001 ending in the lake proposed as a reservoir for the hydropower project under investigation. At the stakes 13.0 and 15.0 coloured powder was spread out on the surface in $5 \times 5 \mathrm{~m}$ squares.

\section{Detailed photogrammetric glacier mapping}

The photogrammetric mapping programme is in response to increasing demands for detailed glacier maps covering the areas under investigation. A prototype map has been produced covering the ice margin of the Inland Ice and the adjoining ice free area north-east of Jakobshavn between $69^{\circ} 20^{\prime} \mathrm{N}$ and $69^{\circ} 33^{\prime} \mathrm{N}$. This includes the snouts and lower parts of six outlet glaciers (inventory nos. 1GC04001, 1GE08001, 1GE07001-2, 1GE04001-2).

Plotting is based on vertical aerial photographs from 26 June 1959, and the map scale is 1:25000 with contour intervals of $50 \mathrm{~m}$ in the ice-free area and $10 \mathrm{~m}$ on the ice. The map was prepared at the GGU photogrammetric laboratory using a Kern PG-2 stereo-plotting instrument connected to a computer system. As pointed out by Schytt (1966) the content of glacier maps depends on the nature of the study under consideration. To meet current

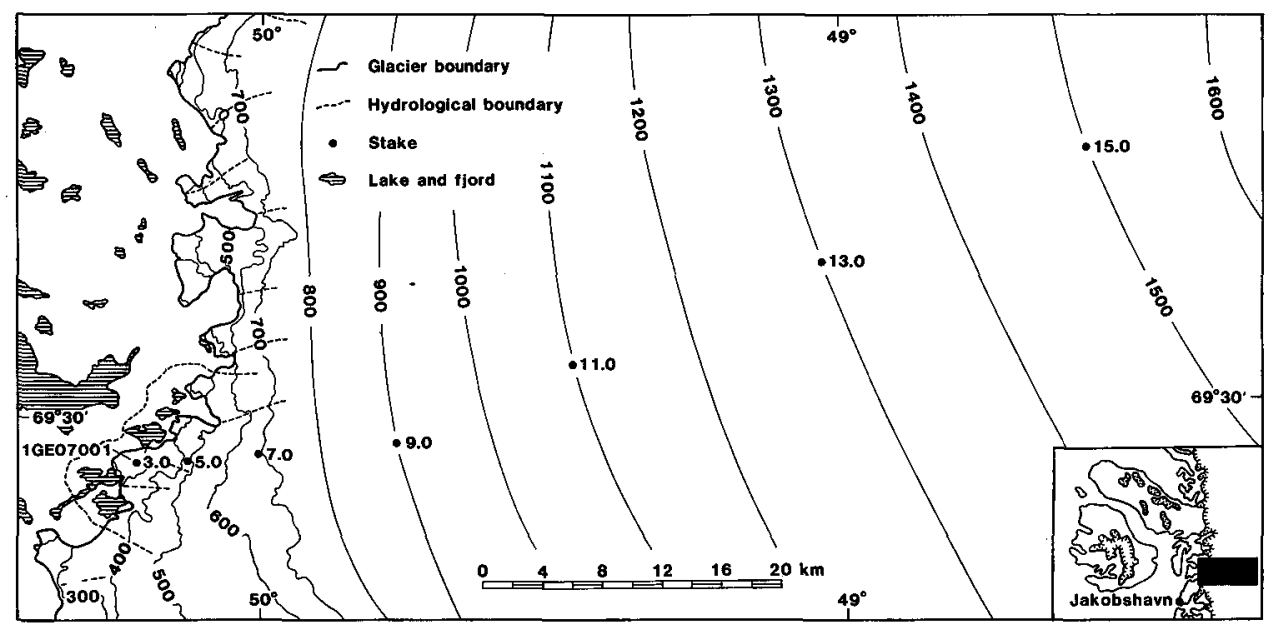

Fig. 38. Drainage basin at Pâkitsoq. Stakes drilled into the ice are shown. 
demands and for possible future uses of the maps, all possible details have been plotted for the glacier area and trim-line zone. The different kinds of information such as contour lines, moraines, lakes etc. are stored on magnetic tape under separate labels, so that copies of separate features can be produced when needed. A section of the prototype map with full information is shown in figure 39. For studies of glacier variations, profiles of the glacier surface and trim line zone in selected areas have been plotted separately.

Future work. A new map based on an aerial survey carried out in August 1982 will be plotted covering the area north-east of Jakobshavn, and a map showing the change of thickness of the ice in the period 1959-1982 will be drawn.

In addition, detailed glacier mapping is planned for an area covering the Inland Ice margin north-east of Frederikshåb between $62^{\circ} 11^{\prime} \mathrm{N}$ and $65^{\circ} 25^{\prime} \mathrm{N}$. This includes the snouts and lower parts of five outlet glaciers (inventory nos. 1BG03001-2, 1BI03001-2, 1BI02001).

\section{Digital analysis of Landsat imagery}

A large part of the runoff from several drainage basins proposed for hydroelectric installations in West Greenland is made up of meltwater from the Inland Ice. It is therefore important to get information about the actual drainage area on the ice.

As pointed out by Weidick (1981) there are special problems in delineating individual ice streams of the Inland Ice, especially at higher altitudes.

Furthermore, it has been suggested by glaciological investigations in South Greenland (Clement, 1982) that the surface drainage patterns inferred from maps may not reflect the actual subglacial drainage patterns.

Use of Landsat images. As pointed out by Krimmel \& Meier (1975), Landsat images offer several advantages over other available methods for observing glaciers. In the current situation a regional view is offered, and large parts of the Inland Ice not covered by aerial photographs can now be seen on one frame.

Computer processing of digital Landsat tapes can detect flowline patterns, crevasse patterns and supraglacial streams, all of which can be related to meltwater drainage according to Stenborg (1973).

Landsat images taken under conditions of low sun-angle often accentuate subtle regional topographic features which reflect the subglacial topographic relief. Detection of these features makes it possible to estimate the subglacial drainage pattern.

Digital image processing. The computer processing of digital Landsat tapes (MSS data) has been worked out on the Interactive Digital Image Manipulation System at the Technical University of Denmark. Digital image maps have been produced covering part of the western slope of the Inland Ice between $61^{\circ} 00^{\prime} \mathrm{N}$ and $70^{\circ} 00^{\prime} \mathrm{N}$. The geodetic correction is based on points identified on maps of scale 1:250000.

Contrast stretching based on frequency distribution of the grey tone values in the images has been used to increase the ability to detect the surface features on the ice. An example of the value of contrast-enhancement for a part of the Inland Ice near Isortuarssûp tasia West Greenland is shown in figure 40 . Contour maps based on digitized contour lines have been drawn, so that the geodetic, corrected and contrast-enhanced Landsat images can be interpreted together with the elevation information. 

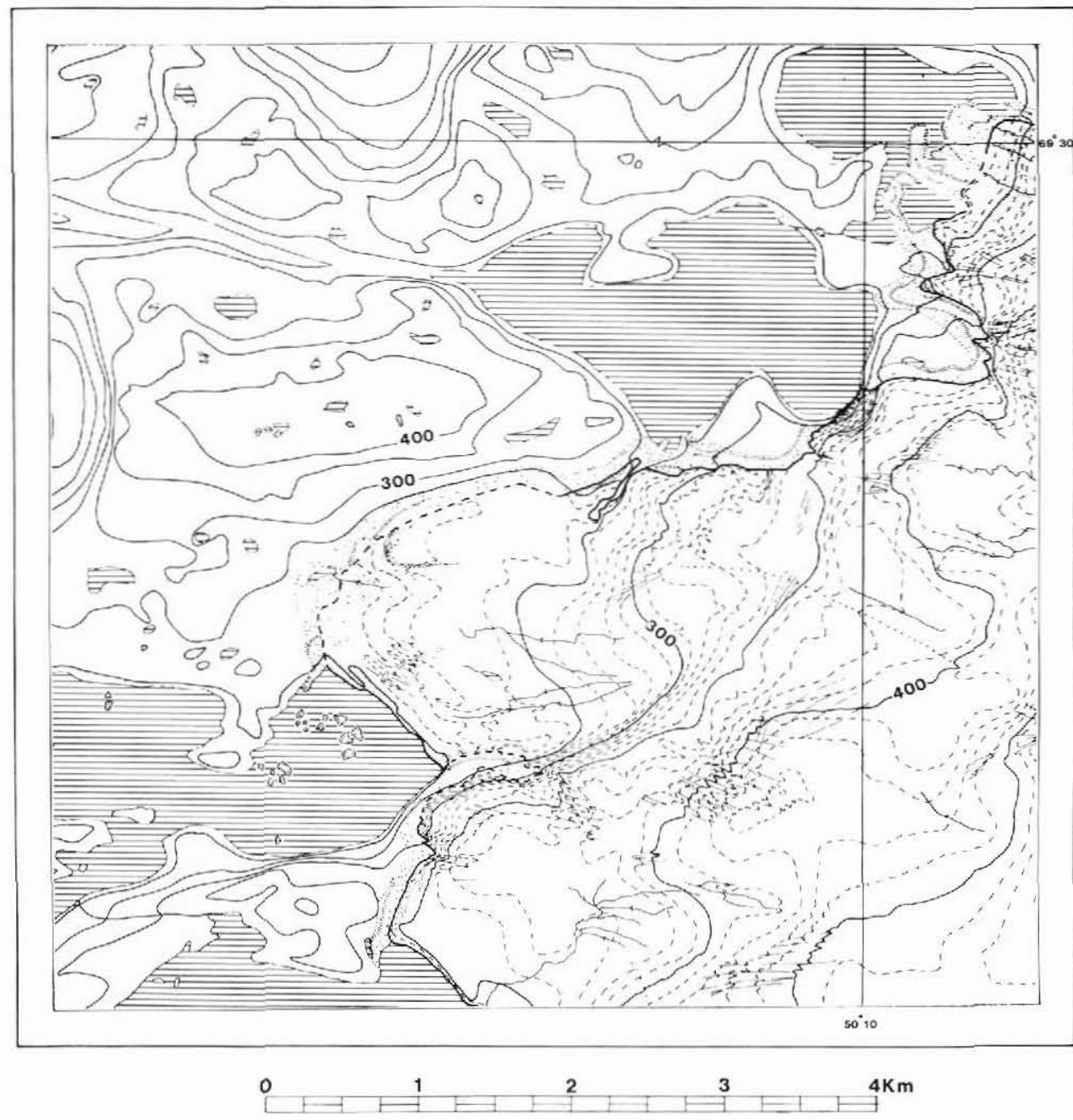

if Contour on ice $10 \mathrm{~m}$ interval

$\$ Ice margin

Crevasse

$\because$ Lineation

\section{Debris covered ice}

\section{$y:$ stream (active inactive)}

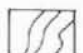

Contour on land

$50 \mathrm{~m}$ interval

Trim line zone

Moraines

Glaciofluvial ridge

Glaciofluvial deposits

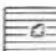

Lake and fjord with icebergs

Fig. 39. Section of prototype glacier map, showing a part of the Inland Ice margin in 1959 north-east of Jakobshavn. 

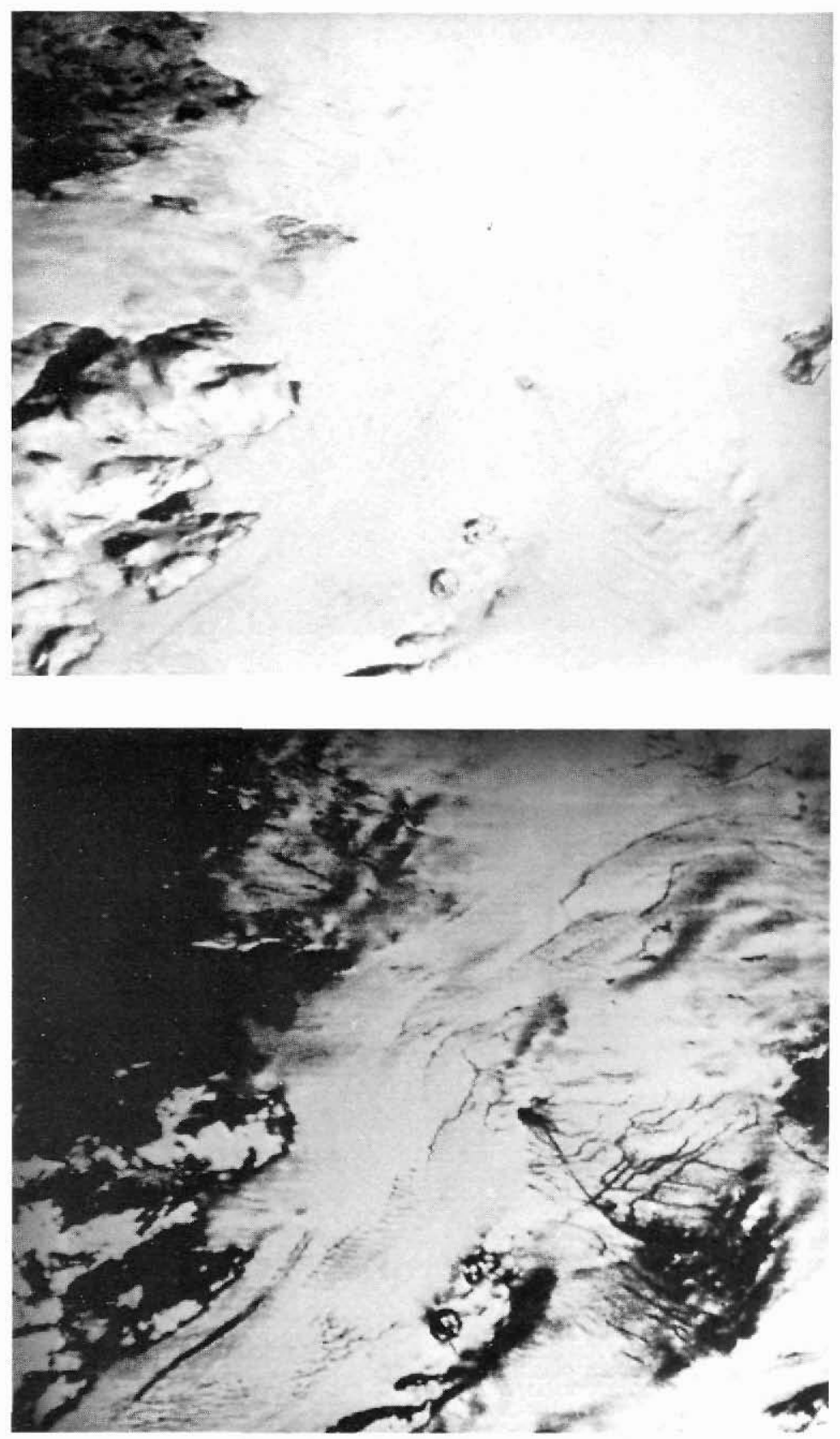

Fig. 40. Contrast enhancement of Landsat 2, MSS 7 data, acquired 23 September 1979. a) Original image with no contrast enhancement; b) Contrast stretched image. 
Acknowledgements. I thank Olav Winding (GGU) and Hans Jepsen (GGU) for orientation of the models, contour plotting and useful discussions about the map preparation.

\section{References}

Clement, P. 1982: Glaciological investigations in connection with hydropower, South Greenland. Rapp. Grønlands geol. Unders. 110, 91-95.

GTO 1982: Forundersøgelse, Vandkraft 1981 Ilulissat/Jakobshavn. Rapp. Grønlands Tek. Org., 43 pp.

Krimmel, R. M. \& Meier, M. F. 1975: Glacier applications of ERTS images. J. Glaciol. 15(73), 391-402.

Schytt, V. 1966: The purpose of glacier mapping. Can. J. Earth Sci. 3, 743-746.

Stenborg, T. 1973: Some viewpoints on the internal drainage of glaciers. Symposium on the hydrology of glaciers, Cambridge, 7-13. September 1969. Publ. int. Ass. scient. Hydrol. 95, 117-129.

Weidick, A. 1981: Status of the West Greenland Glacier Inventory 1980. Rapp. Gronlands geol. Unders. 105, 66-67.

\section{Glaciological, glacier-hydrological and climatological investigations around $66^{\circ} \mathrm{N}$, West Greenland}

\section{Ole B. Olesen and Jørn-Ole Andreasen}

As part of the GGU programme for the regional mapping of the hydroelectric potential of West Greenland, glaciological, glacier-hydrological and climatological investigations were carried out at three local ice caps near latitude $66^{\circ}$ in West Greenland. Two of the ice caps, Sukkertoppen ice cap and 'Amitsulôq ice cap', contribute to the runoff from the Tasersiaq basin (fig. 41) while the third, Qapiarfiup sermia, drains into a smaller basin east of Sukkertoppen.

Investigations in the Tasersiaq basin were started by GGU in August 1981 (Olesen, 1982) while glaciological measurements at Qapiarfiup sermia were started in March 1981.

\section{Glaciological investigations}

The 'Amitsulôq ice cap' covers an area of $165 \mathrm{~km}^{2}$ and lies between approximately 700 and $1400 \mathrm{~m}$ above sea level in the easternmost part of the Tasersiaq basin. Field work started in early June by measuring the winter balance of the ice cap in eight snowpits and drilling down new stakes up to a total of 27. During the summer, transient balance was measured within this network. Naturally the more remote stakes were only visited a few times while stakes near the base camp were measured on a nearly day-to-day schedule.

In addition to mass balance measurements, some of the stakes were surveyed from fixed 